\title{
15 Beyond COVID-19: building the resilience of vulnerable communities in African food systems
}

\author{
Lilian Nkengla-Asi, Marc J. Cohen, and \\ María del Rosario Castro Bernardini
}

\section{Introduction}

The coronavirus pandemic lays bare the inequality and inefficiencies that pervade current food systems. Paradoxically, the very people who grow, process, package, and distribute food are being left behind, particularly women, youth, indigenous people, and immigrants.

This chapter offers a preliminary assessment of gendered impacts of COVID-19 on global food systems, hunger, and resilience. It focuses on the effects of the pandemic on smallholder farmers, particularly women, and examines inclusive policy options that foster progress toward zero hunger, climate-resilience, and gender equality by 2030 .

The chapter centers on sub-Saharan Africa (SSA), as the region faced severe food-security challenges even before COVID-19. Its population living with hunger rose by 16 per cent between 2015 and 2019, reaching 234.7 million people, accounting for more than one of every three food-insecure people on earth. At 22 percent, SSA's food insecurity was substantially higher than the global figure of 8.9 percent (FAO et al., 2020). The prevalence of both moderate and severe food insecurity is significantly higher for African women than for the continent's men (FAO et al., 2020). Gender inequality in food insecurity stems from formal and informal discrimination that women and girls face in societies at large and within their households, in Africa and elsewhere (Botreau and Cohen, 2020). The pandemic has significantly exacerbated SSA's gender unequal food insecurity.

\section{COVID-19's impact on food systems}

COVID-19 has caused major disruptions in economic activities across the world, including SSA. The World Bank (2021) has estimated that economic 


\section{Lilian Nkengla-Asi et al.}

growth across the region declined from 2.4 percent in 2019 to 3.7 percent in 2020. This would be SSA's first recession in a quarter century, with major impacts on poverty and food insecurity. COVID-induced economic and social disruption has led to rising food prices, jeopardizing food access, availability, and affordability.

The pandemic has serious negative effects on food security in Southern and Western Africa in particular (Oxfam, 2020a, 2020b), interacting with other pre-existing crises such as climate change, locust disasters, and violence to create profound negative synergies. In East Africa, the food systems were already under strain pre-COVID-19. The population now faces a "triple menace" as heavy floods make it difficult to contain the locusts and the pandemic (cited in UN, 2020). With limited mobility and decreased consumers' purchasing power, food producers, workers, and market vendors lose opportunities to earn a viable income and supply food within and beyond their communities. Farmers have limited ability to access resources, plant, harvest, and sell their goods. Consequently, in early 2021, a spike in global hunger appears to be imminent as people are forced to make difficult decisions on how to use increasingly limited resources.

Furthermore, workers in the informal economy - including women, youth, and migrants - are particularly vulnerable. A rapid survey of businesses in Uganda suggests that lockdown measures reduced business activity by more than half and finds that micro- and small enterprises experienced a larger decline in activity compared to medium and large enterprises (Lakuma et al., 2020). Similarly, real-time survey data from Senegal, Mali, and Burkina Faso suggest that on average, by the end of April 2020, one out of four workers lost their jobs and one out of two workers experienced a decline in earnings. Informal sector workers are at higher risk, as they generally rely on daily sales for their earnings, lack mechanisms for collective bargaining, and tend to be in intensive activities (Balde et al., 2020).

Oxfam's partner in Zimbabwe, Knowledge Transfer Africa (KTA), using technology to provide market information on farm produce, reported that the threat of temporary closure of Mbare Musika market in Harare triggered panic buying and price increases of 257 percent for a head of cabbage and 33 percent each for $20 \mathrm{~kg}$ of sugar beans and a bucket of maize, the main staple (Dhewa, 2020). COVID-19-induced price increases put basic food stuffs beyond the reach of many urban people whose income streams have been strained by the lockdown (Oxfam, 2020a).

\section{Exacerbating gender inequality}

COVID-19 is much more than a health crisis. It has exacerbated gender inequality as women, particularly those from marginalized ethnic groups 
and communities, feel the consequences most acutely. Before the pandemic, around 50 percent of employed women in sub-Saharan Africa derived their income from agriculture (FAO, 2011) and faced challenges due to disempowering social norms (Berkhout et al., 2021). A higher percentage of women workers in SSA are concentrated in insecure informal sector employment, with less access to social protection; 92 percent, as compared to 86 percent of men workers. Outside of agriculture, the gender gap in informal employment is even larger; 83 percent of women workers compared to 72 percent of men (Bonnet et al., 2019). Likewise, a survey of pandemic-related business closures in three SSA countries (Ghana, Kenya, and Nigeria) found that women-owned businesses closed at a higher rate than those owned by men (Figure 15.1). COVID-19 also affects women and girls by adding to their care responsibilities.

Women play a pivotal role in ensuring household food security. Women and girls are at greater risk of experiencing negative impacts in contexts of crises due to existing gender discrimination and find themselves excluded from high-level policy debates and mitigation efforts (Botreau and Cohen, 2020; Berkhout et al., 2021). Rising poverty and hunger, along with lack of access to essential services in rural areas (De la O Campos et al., 2018), put women and girls at greater risk during crises. Without genderresponsive interventions, women and girls in rural areas face low access to knowledge, services, and technologies, limiting their access to COVID19 information and creating challenges to follow protection measures

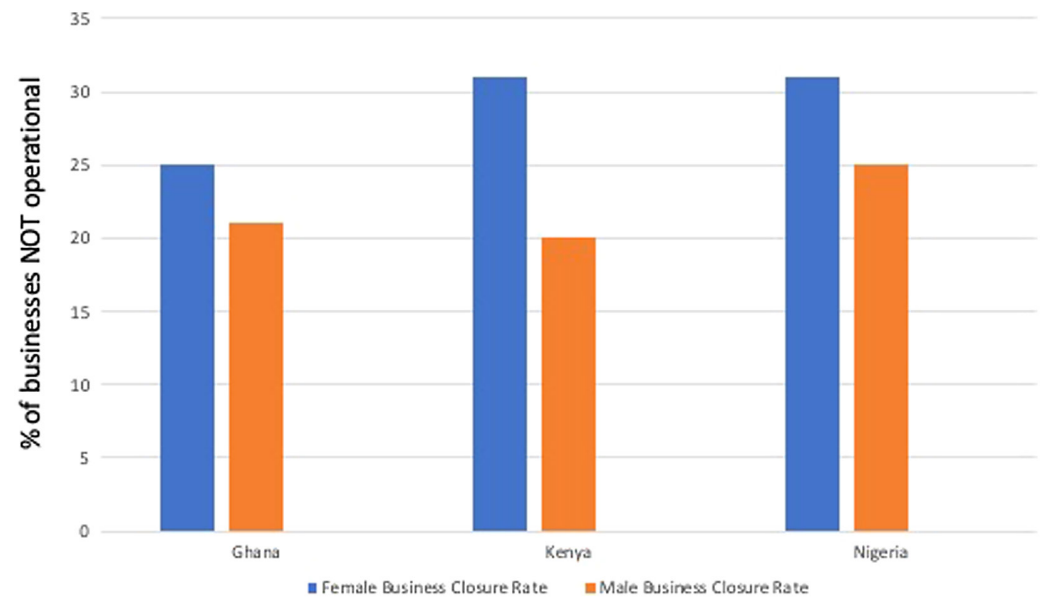

Figure 15.1 Business closure gender gap in Ghana, Kenya, and Nigeria (IDA, 2020). 


\section{8}

Lilian Nkengla-Asi et al.

such as hand-washing, staying at home, and maintaining social distance (Quisumbing et al., 2020).

Food security and agriculture-related policies and practices are often gender-blind or biased, limiting women's access to critical resources such as land, seeds, markets, finance, extension services, farm labor, climate information, and decision-making processes (Botreau and Cohen, 2020; FAO, 2020). Initial assessments of gender-related impacts of COVID-19 emphasized the economic effects of the pandemic on rural women's assets and livelihoods. Evidence from Bangladesh and Uganda shows that women's assets are usually sold first in a crisis, and that when a family member dies, inheritance practices often exclude women (Quisumbing et al., 2020). Bone, a 43-year-old petty trader and mother of eight children in Liberia, lost her job. Like many other Liberian women, she is her family's sole earner and also responsible for caring for her children and extended family. Bone told Oxfam, "I and my children ate two meals a day prior to COVID but now, it is either one meal a day or none" (Johnson-Mbayo K. B., 2020). COVID-19 is likely to exacerbate these challenges, leaving women farmers and traders less able to cope with shocks from crises.

Women around the world experience the burden of unpaid care and domestic work (CARE, 2020; Oxfam, 2021). Women workers find it challenging to integrate their work responsibilities with added care and domestic responsibilities in the context of school closures and mobility restrictions. When mothers need to leave the house to work during the pandemic, it typically falls on girls to take on unpaid care and domestic work (FAO, 2020). An interview with women refugees in Bria in the Central African Republic revealed that women often had increased responsibilities to care for children, the sick, and elderly, further exposing them to COVID-19. One displaced woman said, "It is often women who wake up early to take care of the home, go fetch water, and go to the market. Women are exposed and very vulnerable." The vice chair of the community protection structure added, "It is women who support their families with the small amount of money they have saved" (Oxfam, 2021).

Violence against women and girls rapidly increased in the wake of restrictions and lockdowns as families witnessed increased stress caused by losses of jobs, income, and food security. According to UN Women (2020), 243 million women and girls reported experiencing sexual and intimate partner violence during the pandemic. A study in Southern African Development Community member states indicates that in the first week of lockdown GBV increased as families spent more time at home together (Amnesty International, 2021). The South African Police Service (SAPS) reported receiving over 2,300 calls for help related to gender-based violence during the first week of lockdown (Amnesty International, 2021). Similarly, 
in Zimbabwe, local NGOs witnessed a spike in domestic violence during the first week of April (Amnesty International, 2021). Although conclusive data is not available, COVID-19-related conflicts and tensions could be exacerbating the risk of domestic and gender-based violence for rural households (FAO, 2020).

COVID-19 disproportionately impacts girls' education across Africa. School closures have led to increased unwanted pregnancies and early marriages. A rapid assessment conducted by the South African government found that almost 13,000 under-aged girls got pregnant and about 40,000 got married during a five-month school shutdown (Chisanje, 2021). One girl in Malawi who had completed primary school was looking forward to secondary when COVID-19 started. After COVID-19 struck, she had to stay home for five months due to school closure. During the break, her father married her off to an older man in a nearby village. "I am so devasted that I won't be able to attend secondary school because of what my father is forcing me to do," she said.

\section{Policy issues for inclusive and gender-responsive food systems in Africa}

African governments recognize the importance of gender-responsive agriculture and sustainable development particularly during crises. COVID19 caused a scramble among governments to boost health and immediate COVID-19 response measures, meaning greater pressure on resources available for investment in sustainable agriculture and food security (Maeresera and Chikowore, 2020). COVID-19 revealed the fragility of health infrastructure and absence of social safety nets in many SSA countries which particularly affects women and the vulnerable. The pandemic offers a unique opportunity to reflect on what is needed to develop a food system that is gender-transformative, resilient, and sustainable. Such a system would ensure that the changes we make now will enable communities to better prepare for and respond to future shocks.

African Union (AU) member states agreed in 2003 to devote a minimum of 10 percent of their budgets to agriculture and reiterated this pledge for inclusive and sustainable agricultural development in the 2014 Malabo Declaration. Out of 49 member states reporting on the Malabo commitments during 2017 and 2018, just four were on track, and only Uganda made progress on achieving zero hunger by 2025 (AU, 2020). Moreover, the quantitative pledge of 10 percent of public expenditures to agriculture does not include specific targets to address the needs and aspirations of women and men smallholder farmers. 
For their part, aid donors have underinvested in agriculture and rural development. Data from FAO and OECD indicate that in 2018, donors provided US $\$ 7.5$ billion to the sector (in constant prices), accounting for less than 4 percent of all aid disbursements. Africa received the largest share of aid to agriculture of any global region, 39 percent. Two-thirds of all global aid disbursements to agriculture had gender equality as either its main purpose or a significant consideration.

\section{Conclusion and policy recommendations}

Governments in Africa should focus their agricultural development spending on women and men smallholder farmers. Sustainable, climate-resilient approaches should target women farmers, particularly their access to productive resources and services. Beyond increasing expenditures, governments and donors should create an enabling environment for women to exercise their rights and engage in active citizenship on policies that affect them.

Policymakers need to put gender justice at the core of policies aimed at addressing social inequalities and COVID-19's impacts (Hidrobo et al., 2020; CARE, 2020). Women must be represented in leadership in the design and implementation of social protection measures, welfare systems, and policies; collection and analyses of sex-disaggregated data are fundamental for gender-related impact assessment of crises and evidence-based formulation of policies to advance gender justice in rural areas (Feed the Future, 2020; Botreau and Cohen, 2020).

Governments should ensure that grassroots groups and women's rights organizations participate in budget decision-making. An example is the effort by the Economic Community of West African States (ECOWAS) network of parliamentarians for gender equality and investment in agriculture and food security coordinated by FAO, the International Institute for Sustainable Development (IISD), and Oxfam. It has played a key role during COVID-19 by creating awareness and sensitizing governments through webinars on the urgent need for inclusive and gender-equitable agricultural investment. It brought together parliamentarians from Africa, Europe, Latin America, and the Caribbean to reflect on their role in tackling the crisis to address rural women's needs and priorities on food security and nutrition (IISD, 2020).

Governments should adopt policies and regulations that promote good agricultural practices and benefit vulnerable people. Governments should provide incentives such as lifting value-added taxes, and duties imposed on food businesses to enable the smooth functioning of supply chains. 
Government authorities should work with food companies, retailers, and private sector actors for an inclusive, transparent, and sustainable supply chain. Ghana's government has rolled out the Corona Virus Alleviation Program (CAP) to address economic, social, and health challenges that has provided food to 400,000 individuals in the areas affected by restrictions (Danquah et al., 2020). In a recent declaration, African Ministers of Agriculture committed to ensuring that measures are in place during the pandemic to support food security and nutrition for all (Trust Africa et al., 2020).

Ultimately, COVID-19 has brought to light the need for profound systemic transformation that includes recognition of the value of unpaid and underpaid care work, mainly supported by women and girls; the implementation of universally accessible social protection programs (Berkhout et al., 2021); and intensified gender-inclusive efforts to achieve equitable food systems.

\section{References}

Amnesty International (2021) Treated like furniture: Gender-based violence response in Southern Africa. London, UK: Peter Benenson House.

AU (African Union) (2020) Second biennial review report of the AU Commission on the implementation of the Malabo Declaration on Accelerated Agricultural Growth and transformation for Shared Prosperity and Improved Livelihoods. Addis Ababa: AU.

Balde, R., Boly, M., \& Avenyo, E. (2020) 'Labour market effects of COVID-19 in Sub Saharan Africa: An informality lens from Burkino Faso, Mali, and Senegal'. Working Paper Series, Maastricht Economic and Social Research Institute on Innovation and Technology (UNU-MERIT).

Berkhout, E., Galasso, N., Lawson, M., Rivero Morales, P.A., Taneja, A., \& Vázquez Pimentel, D.A. (2021) The inequality virus: Bringing together a world torn apart by coronavirus through a fair, just, and sustainable economy. Oxfam International.

Bonnet, F., Vanek, H., \& Chen, M. (2019) Women and men in the informal economy: A statistical brief. Manchester, UK: WIEGO.

Botreau, H. \& Cohen, M.J. (2020) 'Gender inequality and food insecurity: A dozen years after the food price crisis, rural women still bear the brunt of poverty and hunger' in Cohen, M.J. (ed.) Advances in Food Security and Sustainability, Volume 5. Cambridge, MA: Academic Press, pp. 53-117.

CARE (2020) Building forward: Creating a more equitable, gender-just, inclusive, and sustainable world. CARE International.

Chisanje, S. (2021) 'Safeguarding girls' education from COVID-19 ills', Oxfam in Southern Africa Told by Exposure (Covid-19 One Year Anniversary Opinion and Commentary Series), 24th February. 


\section{Lilian Nkengla-Asi et al.}

Danquah, M., Schotte, S., \& Sen, K. (2020) 'COVID-19 and employment: Insights from the Sub-Saharan African experience'. The Indian Journal of Labour Economics, 63(1), pp. 23-30.

De La O Campos, A.P., Villani, C., Davis, B., \& Takagi, M. (2018) Ending extreme poverty in rural areas: Sustaining livelihoods to leave no one behind. Rome: FAO.

Dhewa, C. (2020) 'Guest Column - The Musika COVID-19 dilemma: Closing markets will save lives, but it will also ruin them'. newZWire, 27 March.

FAO (Food and Agriculture Organization of the United Nations) (2011) The state of food and agriculture: Closing the gender gap for development. Rome: FAO.

FAO (2020) Gendered impacts of COVID-19 and equitable policy responses in agriculture, food security, and nutrition. Rome: FAO.

FAO, IFAD, UNICEF, WFP, \& WHO (2020) The State of food security and nutrition in the world 2020: Transforming food systems for affordable healthy diets. Rome: FAO.

Feed the Future (2020) 'Gender responsive policy systems for inclusive and effective COVID-19 response'. Agrilinks, 12 August.

Hidrobo, M., Kumar, N., Palermo, T., Peterman, A., \& Roy, S. (2020) 'Gendersensitive social protection: A critical component of the COVID-19 response in low- and middle-income countries', IFPRI Issue Brief 2020. Washington, DC: IFPRI.

IDA (International Development Association, World Bank) (2020) Responding to the emerging food security crisis. Washington, DC: IDA.

IISD (International Institute for Sustainable Development) (2020) 'Parliamentarians Action for Gender Equality and Food Security as a Response to COVID-19', Webinar, 17 June 2020.

Johnson-Mbayo, K.B. (2020) 'A family struck by hunger due to coronavirus'. Oxfam in West Africa.

Lakuma, P.C., Sunday, N., Sserunjogi, B., Kahunde, R., \& Munyambonera, E.F. (2020) 'How has the COVID-19 pandemic impacted Ugandan businesses? Results from a business climate survey', Economic Policy Research Center, Special Issue No. 01.

Maeresera, E. \& Chikowore, A. (2020) 'Will the Cure Bankrupt Us? Official development assistance and the COVID-19 response in Southern African countries', Oxfam \& AFRODAD Joint Agency Briefing Note.

Oxfam (2020a) 'Coronavirus could increase hunger for over 40 million in Southern Africa', Oxfam International, 4th June.

Oxfam (2020b) 'COVID-19: 50 million people threatened by hunger in West Africa', Oxfam International, 21st April.

Oxfam (2020c) 'The Hunger Virus: How COVID is fueling hunger in a hungry world', Oxfam Media Briefing, 9th July.

Oxfam (2021) 'Effects of COVID-19 to women', Video, Oxfam Facebook, 15 March 2021.

Quisumbing, A., Kumar, N., Meinzen-Dick, R.S., \& Ringler, C. (2020) 'Why gender matters in COVID-19 responses - now and in the future' in Swinnen, J 
\& McDermott, J. (eds.) COVID-19 and global food security. Washington, DC: IFPRI, pp. 88-90.

Trust Africa, CNC, ESAFF, \& Oxfam (2020) 'The impact of COVID-19 on smallscale farming, food security, and sovereignty in Africa'. AU Lobby Note.

UN (United Nations) (2020) 'The impact of COVID-19 on food security'. Policy Brief.

UN Women (2020) 'The shadow pandemic: Violence against women and girls and COVID-19'.

World Bank (2021) Global economic prospects, January 2021. Washington, DC: World Bank. 
